\title{
HUMAN HEALTH AS A PHILOSOPHIC PHENOMENON AND AN IMPORTANT COMPONENT OF NATIONAL SECURITY AND STATE SOVEREIGNTY POTENTIAL
}

DOI: 10.36740/WLek202005129

\author{
Yaroslav F. Radysh, Raisa 0. Moiseyenko, Vasyl M. Mykhalchuk \\ P.L.SHUPYK NATIONAL MEDICAL ACADEMY OF POST-GRADUATE EDUCATION, KYIV, UKRAINE
}

\author{
"VALETUDO MAGNUM BONUM EST!" \\ (HEALTH IS THE GREATEST WEALTH) \\ "SOVEREIGNTY IS AN ABSOLUTE AND CONSTANT POWER."
}

JEAN BODIN

\begin{abstract}
The aim: Examination of the human health problem as a philosophical phenomenon and an important component of national security and potential of the state sovereignty. Materials and methods: The authors have analyzed scientific data (7 references) using methods of systemic approach and systemic analysis.

Conclusions: The population health was always and is currently a state priority in civilized countries. Ukrainian researchers have no doubt the problem "Population health and state security and defense" needs the participation of not only medical specialists, but also of sociologists, economists, ecologists, politicians; this problem is a poly-disciplinary one. Reforms in the health care field of Ukraine are to solve an especially important and urgent task - strengthening of Ukrainian people health. The essence of concepts «national security» тa «sovereignty of the state» being conditioned to a significant degree by the health state of our citizens leads to affirmation the steadfast state sovereignty to be a factor ensuring the stability and high level of national security.

It is currently of the greatest importance to take into consideration all the possible configurations of future having determined strategic priorities and preparing favorable conditions for steadfast development. Currently, such development is dependent on the level of community health and quality of state government.
\end{abstract}

KEY WORDS: health of citizens, national security, potential of the state sovereignty

Wiad Lek. 2020;73(5):994-999

\section{INTRODUCTION}

Hippocrates, a well-know philosopher and "teacher of all physicians", was sure the health to be the greatest human's richness; Cicero confirmed the highest welfare cannot be attained without physical, psychic, and mental health of full value. A German philosopher A. Schopenhauer wrote the health to exceed absolutely all the other life welfares, a healthy beggar being in truth happier than an ill king.

Since olden times the population health was among national priorities of any civilized state. The UNO considers the population health as an index being a determining one for the national development. When the health problem is considered in the context of national security and defense, it becomes also a factor of strategic importance. The human history experience confirms any diseased population to be incapable to stand upon neither its security not its native interests. Some evolutional changes had place in the course of time, mental health demanding now more attention comparing to past epochs. It is completely clear the modern state security and defense are realized using a lot of informational and other high technologies, complex machines and devices. Such a situation demands not only adequate education but also person's ability to go through a lot of nervous and psychic difficulties; besides, extreme conditions are often present.

No Ukrainian and foreign researchers have doubts the problem "The population health and national security and defense" to need not only the participation of medical workers, but also the work of sociologists, economists, politicians, ecologists: it is a multi-disciplinary problem. Its complication is associated with necessity to find all the interrelations and to evaluate the characters of different factors effect, these factors being however, innumerable. It is extremely difficult to indicate a factor without any effect on the health; however, there are decisive factors being health determinants. Among them, there are such ones as demographic processes, reproduction of population, death rate, state of natural and industrial environment, prevalence of socially important diseases (blood circulation disorders, oncology-related processes, psychics and 
behavioral disorders, reproductive ones, traumatism etc.) as well as socially dangerous diseases (tuberculosis, HIV/ AIDS, different infectious hepatitis, alcoholism, drug abuse etc.). The analysis should include such social phenomena as unemployment, poverty, work migration, education level, social security and welfare. Every of these components as well as a lot of other ones having been yet not concretely determined have a doubtless and a rather significant effect upon the population health and state security.

Taking into account all these data discussed above, we conclude the maintenance of population health care in Ukraine deviates from the framework of a specific medical problem and becomes a national and inter-sectional one requiring its solution on the national level.

\section{THE AIM}

Aim of the study was examination of the human health problem as a philosophical phenomenon and an important component of national security and potential of the state sovereignty.

\section{REVIEW}

According to the opinion of prominent specialists, the leading place in the values system of any civilized nation belongs to the human health. From the point of view of any individual and of society level, it is impossible to find any other phenomenon whose role is equal or exceeds the significance of human health due to its unconditional influence on any sphere of human activities. The demographic crisis being currently evident increases the attention to population health from the point of view of labor reserves reproduction in Ukraine.

Our analysis of available numerous medico-social studies data confirms the health to be conditioned by social factors, the state of Ukrainian citizens health as well as of national health care branch being a reflection of economical development of our country, direction of its state politics, and, first of all, of attention being paid to social problems and to accumulation of "human capital". Being a qualitative character of economically active population, the state of the nation health stipulates directly for the labor productivity level in the society and influences significantly upon the perspectives of its socio-economical development. However, the absence of the health ideology in our country as well as of conscious attitude of citizens to their own health leading to the health maintenance and strengthening confirms the health inflation in our country. Ukraine being currently on the stage of total state management transformation, the process of change realization in the health care system becomes significantly complicated, although the effective health care management is a significant contribution for achievement of worthy life standards for our population and for state defense.

The main aim of philosophical analysis of health and disease phenomena is directed, first of all, on elucidation of their interconnection with the sphere of human will, with personal individual choice concerning his/her certain type of being (existence). From the point of view of philosophy, the health is a form of body potencies existence giving a possibility to realize maximally all the possibilities of human auto-realization. In this case the personal aim to be healthy includes the "inalienable responsibility for person's own being".

Sociological investigations of health include, first of all, such problems as social stipulation for society health in the system of senso-vital personality values. It should be underlined the sociological health studies concern, first of all, personality attitude to his/her own health. In current social and other conditions the greatest attention should be paid namely to this problem. The most important idea is the increased personal attention to the own health. It should be recognized the health to be not only the most important terminal human value, it possesses also instrumental function becoming often a single means permitting to achieve the aims having been posed and to satisfy a lot of various needs.

From a wide philosophical point of view, the individual health is determined as a significance degree of possible realization by a human of purposeful and understood actions without worsening of human's physical and mental state, without loss of his/her adaptation to the vital environment. The systemic analysis made on the basis of data obtained by Ukrainian and foreign authors and concerning the theme of this study gives the right to confirm the health to have integrative character. However, in this concept three isolated interrelated components can be seen - physical (biological), spiritual (psychical), and social health.

According its physical parameters, the health is expressed by biological (somatic) indices of human's state and its vital activity. Vital health characters disclose the significance of its bio-psycho-social indices being described on individual level, the human being not included into the system of social interactions.

The spiritual health as a value fixes ideal parameters phenomena permitting a human to enjoy his/her full rights in the society.

The health as a social value demonstrates the role of social interactions, of human's place and role in social tasks decisions, human's realization degree of community interests providing the person with satisfactory level of social adaptation. The health as a conception belongs to a complex biological, social, and philosophical category and can be described using a multitude of components related to such concepts as human life and scientific technical progress with all its many-sided aspects [3].

In current conditions the human health state is usually described using the following criteria: absence of disease, normal organism functioning, psychical, physical, and social welfare; ability to work of full value, aspirations for creation, adaptation ability depending on environment changes

The World Health Organization (WHO) has determined the health as the state of complete physical, spiritual, and social welfare, not only as the absence of diseases and phys- 
ical defects. In addition, a significant condition of health is the human ability to realize a harmonic life in environment conditions being perpetually changed.

The "health" conception is a multi-factor one; it is a complex and dynamic phenomenon being interpreted in philosophical, medical, and socio-economical works from different methodological positions. There is a rather wide list including only terms having been long ago and being used currently by Ukrainian and foreign authors in different historical epochs - from Hippocrates to the present.

This task becomes additionally complicated due to necessity of multi-level health evaluation. The professor Yu. P. Lisitsyn proposes to determine three interrelated health levels requiring many-sided approaches - social (of population level), group, and individual approaches.

It should be underlined O. P. Dobroslavin to be the first to interpret clearly the conception of the "health" as a medico-biological and socio-political phenomenon. In particular, he emphasizes the health as a medical concept is thought to be a physiological state of the organism whose functions are realized in normal range. From his point of view, the community (society) health presents the state of the highest work ability corresponding to human's forces sum. O. P. Dobroslavin was namely the first to point out the limited medicine possibilities concerning the realization of sanitary measures; he underlined their national significance connected with state, but not medical character of these measures as well as of health care system concerning health care organization and also elaboration and realization of measures aiming maintenance and strengthening of individual and community health. O. P. Dobroslavin is quite right in his opinions regarding the main health care problems. He is sure the most important tasks are the study of laws determining the firmness of physiological balance in the organism under different conditions of social activity and the study of the most probable conditions of maintenance and development of organism's productive forces. We support the opinion of the well-known researcher professor P. I. Mel'nychenko who points out the health to be an attribute of human being as a biosocial system; this attribute reflects the state of its elements - structure, function, adaptation assuring the realization of qualitative-quantitative ratios in the system "human-environment" as well as the human existence at any adaptogenesis stage: adaptation process, adaptation state (firmness of balance), loss of adaptation $[3,4]$.

According to a WHO-proposed determination (1993), the health is considered as a high potential of human physical, psychical, and mental possibility and a state of complete social welfare. Such interpretation of the "health" concept has been recently completed by an idea the life to be not only protracted, but also of high quality. It goes without saying the ensuring of qualitative and long life, conditions of its maintenance, development, and social adaptation cannot be a function realized only by health care institutions; it is also a state function, a task of its social politics and conditions enabling continuous personality development.
The necessity to use the science arsenal for quantitative health description may be given in terms of power and quantity.

The power expresses the state of structure, function, and adaptation reserves in a given time moment. It is a potential of human and population possibilities concerning the life process realization. Different indices may be taken to determine the health power. First of all, there are some medico-diagnostic approaches characterizing the state of cardiovascular, respiratory, urogenital, endocrine, and other systems. Great possibilities, especially ones concerning the health power evaluation including also the community one, belong to medico-statistical indices (physical development, morbidity, lethality, labor losses).

Combined analysis of medico-statistical and medico-diagnostic indices enables a real characterization of human physical state, nervous, psychical, and immune status, providing of individuals and populations by vitamins; it is possible to determine the degree of patient's pre-morbid state (i.e. state before the disease development) and to identify environmental "risk factors". For quantitative characterization of the data obtained, it is worth to use the values of standard deviations and to build appropriate scales.

Health quantity represents its general reserve during all the life, having been determined by hereditary and social factors. It is worth to be determined using both biological and social indices integrating all positive and negative components of its value. Such indices include the mean life span, labor ability, general condition,

In spite of all the difficulties accompanying these proposed variants of possible determination of health power and quantity, the solving of this task opens the way to objective estimate of social efforts being applied to assure normal life conditions for our country citizens, the health being, in the end, the main criterion of these efforts.

The modern global practice forms a new health philosophy based on the recognition the health to be of the highest value from a lot of aspects and to possess the priority in a line of the most important needs of human and society. The formation of population health and of social medical needs has place under the influence of different factors:

- demographic (quantity of population, its sex-age structure, level of population migration, birth rate, total and children death rate etc.);

- socio-economical (peculiarities of economic development of different territories, peculiarities and level of manufacturing, settling system, population density, state of roads, transport, communication);

- climatic-geographical (geographic and climatic peculiarities, regional peculiarities influencing upon the characters of population morbidity, health care accessibility etc.);

- socio-medical (population morbidity level and structure, level of health care development, resource providing for health care institutions);

- socio-cultural (living and everyday life conditions, financial population level, level of social service devel- 
opment, family state, family quantity and composition, national traditions, levels of culture, education, and public health education).

Thus, we point out once more: the population health state is an integral index of the state social orientation; this index reflects the degree of the state responsibility to its citizens. The maintenance and development of national human capital are recognized to be among priority tasks of the domestic policy of Ukraine in the next future.

Human attitude to his/her own health is a socio-cultural phenomenon with essential special and temporary differences. Unfortunately, our country history with its neglecting of individual life has created stereotypes leading individuals to neglecting their own health maintenance. On the contrary, the western model of individuality domination stimulated the development of health-aiming values and adequate human attitude to his/her health. In spite of changes occurring currently in the Ukrainian society (we mention, first of all, the process of social moral individualization, "privatization" of individual values system etc.), there are practically no changes concerning the attitude of our compatriots to their health. According to the data obtained due to numerous sociological studies concerning the health of different age groups, the real behavior of their representatives does not promote the maintenance and strengthening of their own health. Thus, sociologists conclude average Ukrainians including also young ones consider their own health only as a declared value. In this context, the young men's attitude to their own health determining our country future and the health state of new Ukrainian generations is now a problem of increased anxiety.

The human health level is not only of each individual property, but also a social one; it is a social strategic resource, index of welfare and one of the most important components of the human development index (HDI).

The HDI is an integral index having been proposed for investigations regarding the development of any country potential. Currently, the HDI is a standard index enabling the comparison of life levels possessed by citizens of different countries and regions.

Some researchers affirm the HDI value to be namely the most significant criterion for distribution of different countries into groups with different levels of human development.

Currently, the HDI evaluation is annually carried out in Summary Reports of the ONU considering the human development. Independently on the level of economical development, the list of countries with high levels of human development includes ones with HDI indices reaching 0.8 and higher; the countries with this index values $0.5-0.8$ and below than 0.5 belong to states with average and low human development, responsively

The main cause of the widest HDI use is a relative simplicity of its calculation and a possibility to obtain and use initial data. The components taken for the HDI calculation are: state of the health care system and life expectance (their criterion is longevity); educational level of grown up citizens and coverage (their criterion is erudition), and level of citizens income (GDP per capita) (its criterion is material life level).

The maintenance of health as a capital, as an important part of human capital, belongs to factors determining the state competitiveness on European and global level.

The final aim of the health support is its balance improvement, i.e. the balance between the organism and environment being expressed as physical, psychical, and social well-being of each individual. From the social point of view, the better community health is associated with lower level of disease-caused negative consequences, with increased welfare and life expectance. Health care is a special form of human activity taking part in guaranteeing of human rights to live and be healthy. That is why the health care should be always a priority direction of political, economical, and social state and society activities.

The population quantity in Ukraine is known to be significantly decreased. According to the national statistics data, the population quantity in Ukraine on the $1^{\text {st }}$ of September 2015 reached 42 million 805 thousand 731 persons. The demographic index decrease began to drop drastically from 2013. During two next years the total population quantity dropped by 2 million 654 thousand 564 persons.

As a result of demographic crisis having place during 24 years of the state independence of Ukraine, its population became cut down by 8 million. The specialists in demography affirm such depopulation is yet kept, its rate, however, becoming gradually a little slower.

We give below an opinion of Vasyl Kravtsov, director of the M.I.Dolishni Institute of Regional Investigations (National Academy of Sciences of Ukraine), concerning the current demographic situation in our country:

The depopulation is yet kept in our country, its rate, however, becoming gradually a little slower. ...We confirmed earlier Ukraine to have 52 million inhabitants; this figure reaches currently only 45 million or even less. ...Depopulation had mostly place due to the changes of population quantity in southeast and central regions of Ukraine, by 3.6 and by 2.4 million, respectively. At the same time, the population quantity during this period shortened only by 139 thousand. ...Some west districts of Ukraine - Zakarpattia, Rivne, and Ivano-Frankivsk ones - are leaders in natural population increase. In 2014, the population quantity of Zakarpattia district became higher comparing to 1990 due to the natural population increase, the population of Ivano-Frankivs'k district having become lower only by 10.5 thousand persons. Besides, high permanent birth rate level is seen in Zakarpattia and Rivne districts, these two ones only demonstrating positive population increase results. ... Poor results concerning demography indices are shown by east Ukraine regions; Donetsk district lost almost a million of inhabitants, the losses of Dnipro and Lugansk districts heaving reached in each case almost 500 thousand persons. In addition to depressed Donbas region, the drop of population quantity index is seen also in Sumy and Chernigiv districts, as well 
as in central districts of Ukraine - Kirovograd, Cherkasy, Khmelnyts'k and Vinnytsia districts having lost from 6 up to $8 \%$ of their population during the period from 1990 up to 2014. B central and especially southeastern regions the annual population losses reached 150-200 thousand persons....Such event development is mostly influenced by economical factors as well as economical politics of government and state.... Due to displaced persons, the Kyiv population increased by $8.3 \%$; simultaneously, Zakarpattia and Rivne districts population increases being $0.9 \%$ and $0.1 \%$, respectively.

We become older. Unfortunately, according to the data presented by the newspaper "Express", Ukraine belongs to the first thirty of countries with the highest portion of citizens above 60 . In 2015 this portion reached $21.8 \%$, and besides, $15.5 \%$ of our citizens are 65 years old and elder. According to demographic prognoses, in 2025 a quarter of Ukrainian population will reach the age of 60-65, the portion of citizens above 65 will be as high as $18,4 \%$. In 2030 , these indices will be above $26 \%$ and $20 \%$, respectively.

A question develops what are causes of persistent aging of Ukrainian populations?

One of casual factors of such situation is low birth rate. The quantity of human beings born each year in Ukraine is rather lower comparing to deceased ones. The common birth rate coefficient in 2016 was $10.3 \%$, the death rate coefficient having reached, however, $14.7 \%$. Currently, about 1.6 live-born infants fall on each women of child-bearing age. Representatives of the 1960s' generation (it was a period of high birth rate), will gradually become representatives of the $60+$ category. There are very few citizens born in 2000s. So the portion of pensioners will increase, the youth one decreasing. The situation becomes dangerous.

Currently, about 11-12 million persons work in Ukraine, each of them is to support a pensioner. According to prognoses, in 10 years our country will have only 8 million workers and 13-16 million pensioners, i.e. each worker will be obliged to support 2-3 dependants. So, young people will be forced to work longer becoming pensioners significantly later in order to support the population becoming older. The worst fact is that it is scarcely our present youth will have any social support from the state having reached elderly age. If such a support will be received, it will be very scanty.

During all the mankind history stages, representatives of different sciences and professions were studying the mysteries of the health phenomenon to provide all the means necessary to maintain the health during all the human's life. Currently, the health is not more considered as an especially medical problem. The conviction develops the complex of especially medical tasks to be only an unimportant part of the health phenomenon. The generalized results of studies describing the dependence of human health on different factors convince the state of the health care to determine only about $10 \%$ of all factors having influence upon the health.

\section{DISCUSSION}

A formula (a model) is known indicating the health to be conditioned by the following factors: factors of the life style (by $50-55 \%$ ), environment state (by $20-25 \%$ ), heredity (by $15-020 \%$ ), and state of health care service (by 8-10\%); like a health criterion this modes takes the primary total morbidity of the whole population and of its groups (population level). In any event, the medical aspect, strictly speaking, are not the leading one among various factors influencing upon the human health; so a medical health determination as the absence of disease does not correspond to life realities and needs. It is evident the human health to be a complex phenomenon of global importance which can be considered as a philosophic, social, economical, and medical category, as an object of consumption and of capital investment, as an individual and social value, as a systemic phenomenon being dynamic and interacting perpetually with its environment, the last being, in its turn, perpetually changed.

The fulfillment of the main strategic task concerning the activities of the health care system of Ukraine - maintenance and strengthening of the health of our citizens - is impossible without knowledge of the main peculiarities, tendencies, and laws of Ukrainian people health state. In its turn, the community health level is an important component of national security and an integral (generalized) index of social politics and state government as a whole $[2-4,6]$.

According to the article 1 of the Law of Ukraine the "Backgrounds of the National Security of Ukraine" (19.06.2003, № 964-IV), the national security signifies the protectability of the most vitally important values of human and citizen, of society and state; the maintenance of these values supports the perpetual society development, timely detection, prevention, and neutralization of real and potential dangers for national interests. The article 3 of the Law cited previously determines the objects of national security of Ukraine are human and citizen, their constitutional rights and freedoms; society, its spiritual, moral/ethical, cultural, historical, intellectual, and material values, informational and natural environment as well as natural resources; state - its constitutional state system and territorial immunity and integrity [5].

The human development conception affirms the main instrument necessary to achieve a high level of society welfare is investment in the human capital to ensure the protracted healthy life.

According to some investigators $[1,6]$, the national security of Ukraine is considered as a totality of inter-related elements belonging to heterogeneous functional spheres; their important components are political, economical, ecological, technological, informational, and human (demographic) security.

The analysis of literature concerning our theme permits to assert the population health state to be among the main factors ensuring the high level of all other functional elements determining the national safety. Taking these results into consideration, it is clear the Ukrainian people health 
to be the most important element among national security system components.

Having given a short account of our opinions concerning the role and place of human health in the complex of national security elements, the authors are now to describe shortly their analysis proving the population health significance for ensuring the state sovereignty potential. The "Explanatory Dictionary of Foreign Words" indicates the category "potential" is of Latin origin; it is interpreted as a sum of all available means, possibilities, productive forces which may be used in any field, branch, sphere [8].

According to the opinion of some Russian scientists, the state sovereignty potential has two significant components. The first one is military-political and financial-economical potential. The second component is political, social, and economical potential.

Thus, two components are decisive in the state sovereignty structure. The first one includes possibilities belonging to military, political, and structural potential, degree of the statehood, i.e. possibilities of its economics on the level of global economy. The second component includes possibilities to satisfy the interests of state and its institutions as well as social needs.

\section{CONCLUSIONS}

Sovereignty is a unique power configuration having been created in the course of the mankind historical development. However, the state power (authority) is such that it cannot be jointed with any other state power on the same demographic and territorial field. Such a field may be managed only by a single state. Such a fact namely expresses the exceptionality of sovereignty. Due to this fact, it is necessary to have always in mind problems of the state sovereignty, sovereignties being currently not abolished, but strengthened.

The fulfillment of the leading strategic task in the field of the health care of Ukraine, i.e. the maintenance and strengthening of population health, is impossible without knowledge of the main characters, tendencies, and development directions of the Ukrainian people health state. The level of community health in our country is an important component of national security playing a significant role in the strengthening of the country potential; it presents an integral (generalized) index of our country social politics and of the state government as a whole.

\section{REFERENCES}

1. Nyzhnyk N.R., Sytnyk G.P., Bilous V.T. National Security of Ukraine (Methodological Aspects, State, and Development Tendencies): Teaching Textbook [Natsional'na bezpeka Ukrayiny (metodolohichni aspekty, stan i tendentsiyi rozvytku)]. Irpin'. 2000; 304 (UA).

2. Radysh Ya. Potential of the state sovereignty, its essence, structure, and dimension: experience of Russia (invitation to reflection) [Potentsial suverennosti derazhvy, yiyi sut', struktura ta rozvytok: dosvid Rosiyi]. New Medicine of the Millennium, 2009; 2:36 - 41. (UA).
3. Radysh Ya.F. Human health as philosophic phenomenon and an important component of national security [Lyuds'ke zdorov'ya yak filosofs'kyy fenomen ta skladova natsional'noyi bezpeky]. Scientific Information Herald of the Academy of National Security. 2016; 1-2 (9-10): $20-27$ (UA).

4. Radysh Ya.F. Theoretical and methodical backgrounds of investigation of citizen's health as an important national security factor [Teoretychni ta metodychni osnovy doslidzhennya zdorov'ya hromadyan yak vazhlyvoho chynnyka natsional'noyi bezpeky]. Scientific Information Herald of the Academy of National Security. 2015; 1-2 (5 - 6): 27 - 37 (UA).

5. Sytnyk G.P. State Management in the Field of National Security (Conceptual and Organizational-Juridical Rationales): Manual [Derzhavne upravlinnya u haluzi natsional'noyi bezpeky (kontseptual'ni ta orhanizatsiyno-pravovi obhruntuvannya): Posibnyk]. K.: Edition of the National Academy of the State Government under the Protection of the President of Ukraine. 2012; 544 (UA).

6. Sytnyk G.P., Zavgorodnia S.P. Conceptual backgrounds concerning state employee competences on the field of state security (specialist of public service) [Kontseptual'ni peredumovy shchodo kompetentsiy derzhavnykh sluzhbovtsiv u haluzi derzhavnoyi bezpeky (spetsialist z derzhavnoyi sluzhby)]. Scientific Information Herald of the Academy of National Security. 2015; 1-2 (5-6): 6-26 (UA).

7. Explanatory Dictionary of Foreign Words [Poyasnyuval'nyy slovnyk inozemnykh sliv]. K.: Shkola. 2006; 288 (UA).

The article has been performed within the framework of the following research work: "Substantiating innovative models for managing and optimizing the organization activities of administration agencies, enterprises, public health facilities".

\section{ORCID and contributionship:}

Yaroslav F. Radysh - 0000-0002-3099-2341 C,D

Raisa O. Moiseyenko -0000-0001-6727-8742 ${ }^{A, C}$

Vasyl M. Mykhalchuk - 0000-0002-5398-4758 B,E,F

\section{Conflict of interest:}

The Authors declare no conflict of interest

\section{CORRESPONDING AUTHOR Vasyl M. Mykhalchuk \\ 9 Dorohozhytska Str., Kyiv, 04112 Ukraine \\ tel: +380973885108 \\ e-mail:shepit@ukr.net}

Received: 23.01.2020

Accepted: 01.04 .2020 